\title{
NIETZSCHE, RELATIVISM AND TRUTH
}

\author{
ALBERT CINELLI \\ University Of Kansas
}

Nietzsche's understanding of truth differs from a common sense notion that regards truth as the relation between what is thought to be known, what is understood as true and what is actually the case. According to the common conception, if what is the case and the understanding of it are in accord, truth prevails, if they are not, then there is falsity. Most people, and probably most philosophers, hold to some form of "metaphysical realism" by which they believe that there is something definite "out there" (with the tropic "inside and outside" firmly operative) that can be understood by a knowing mind. Hilary Putnam, ${ }^{1}$ for example, defines this position:

\begin{abstract}
On this perspective, the world consists of some fixed totality of mind-independent objects. There is exactly one true and complete description of "the way the world is." Truth involves some sort of correspondence relation between words of thought-signs and external things and sets of things" (Reason, Truth and History, 49).
\end{abstract}

Nietzsche's theory of truth is a perspectival one, one in which the all knowing, determinately true, "God's eye," omniscient observer's perspective is replaced by a multitude of perspectives. For Nietzsche, the very notion of an overarching ultimate truth is regarded as symptomatic of a kind of philosopher's malfeasance.

The problem faced by any perspectival theory of truth is that it is liable to the criticism that it commits a version of the fallacy of relativism-that, in claiming that all truth is perspectival, the claimant implicitly evokes a universal theory of truth, in that, in order for this theory itself to be true, it must establish at least one universally true proposition (that all truth is perspectival). Such a theory, therefore, by its own measure, cannot be regarded as true, since, either it establishes this one universal truth or the theory itself may also only be a perspective. This argument goes back at least to Plato's Theatelus, and is often posed against Nietzsche's perspectivism, as in, for example, Danto's Nietzsche as Philosopher. ${ }^{2}$ The important question here is how Nictzsche's perspectivism can get around this objection of the fallacy of relativism. However, one might also ask whether Nietzsche even has a unitary theory of truth, or whether it is

\footnotetext{
1 For the record, Putnam disagrees with this position.

2 Though Danto is not fully supportive of this as an argument against Nietzsche.
} 
important that he does. Before a critical analysis of the paradox of relativism is given it is important to see how a theory of truth may be propounded from a reading of Nietzsche's texts.

This account will proceed roughly chronologically from Nietzsche's early manuscript "On Truth and Lies in a Nonmoral Sense," through Thus Spoke Zarathustra, Beyond Good and Evil, "How the 'Real' World at last Became a Myth," from Twilight of the Idols, finally to an account of the doctrine expounded in The Will to Power. The point of this method of selection is first, to establish what Nietzsche's theory of truth is. Secondly, to show some of the consistencies and developments across the whole of Nietzsche's thought. This method is not comprehensive, nor could any method be given this task. In some ways the method is reflective of Nietzsche's own style (though with less ability), jumping from text to text, reference to reference, all comments revolving around a series of related themes.

Nietzsche's 1873 manuscript essay "On Truth and Lies in a Nonmoral Sense," marks an early stage of his development of a theory of truth. Here truth is understood as a product of language, with science being a further product of a linguistic method of discovery that reinforces a notion of truth as certainty in the face of doubt. He calls truth:

"A movable host of metaphors, metonymies, and anthropomorphisms: in short, a sum of human relations which have been poetically and rhetorically intensified, transferred, and embellished, and which, after long usage, seem to a people to be fixed, canonical, and binding" (Philosophy and Truth, 84).

He adds:

"Truths are illusions which we have forgotten are illusions; they are metaphors that have become worn out and have been drained of sensuous force, coins which have lost their embossing and are now considered as metal and no longer as coins" (84).

The thrust of these claims is that truth is a collective convention, one that is the product of uncertain beings who occupy only a temporary place in the vastness of the cosmos. Truth is established as a sort of peace treaty that institutes uniformly valid and binding designations for things. Comfort is derived from this conception, in that one may cease to worry whether all is flux and get on with the business of life. With this rigidification of what is true certainty is established, and also uncertainty. With truth comes the possibility of the lie. By using the established 
designations improperly one can use the language of truth to say what is untrue. There is no falsity outside of these linguistic conventions.

Nietzsche claims that this origin of truth is buried under as humans forget that the notion of truth is a problematic one, one with a history of . development. Humans forget that this truth is an illusory one, "empty husks" are considered solid. This truth is a product of metaphor upon metaphor. The very image we see is metaphor for a nerve stimulus, the word by which we designate this image is itself a further metaphor. In this, there is no relation to any things in themselves.

Nonetheless, it is interesting that in this essay Nietzsche maintains a tension between this manner of metaphysical realism ${ }^{3}$ and the more obvious rejection of this point of view. He cuts short the objection to his perspectivism saying:

"For even our contrast between individual and species is something anthropomorphic and does not originate in the essence of things; although we should not presume to claim that this contrast does not correspond to the essence of things: that would of course be a dogmatic assertion and, as such, would be just as indemonstrable as its opposite (83-84).

Thus, truth is not a lie, but truth and lie only exist in the metaphorized world of rigid designations. Even to say that truth is an illusion must be understood in a specialized sense that the image must not be taken as a true reflection of an absolute reality. Nietzsche denies the possibility of "correct perception." He defends something like the Protagarian position that man is the measure of all things. Furthermore, man brings to all things an interpretation of them. "Things," themselves, are a product of these interpretations.

Although the recognition is made that humans cannot attain to the thing in itself in language or perception, Nietzsche still makes reference an "essence of things" that is apprehensible aesthetically. ${ }^{4}$ He writes:

A painter without hands who wished to express in song the picture before his mind would, by means of this substitution of spheres, still reveal more about the essence of things than does the empirical world (86-87).

Nietzsche only glancingly alludes to what this "essence of things" is really like, and in his last works, such as Twilight of the Idols, this position is

3 In a certain sense, that of an outside world of the really real, whatever that may be.

4 This is the extent of his possible "metaphysical realism." 
explicitly abandoned. Nevertheless the relation of Nietzsche to this "essence of things" does point to some multiplicity of meaning in the Nietzschean text and also points to some of the difficulty in actually putting forth such a radical theory of truth. Nietzsche's, probably deliberate, ambiguity is more apparent and more understandable when one examines the status of truth in Thus Spoke Zarathustra.

To determine a theory of truth in this deeply poetic philosophical work requires some effort of interpretation. We can focus on two brief passages from Books I and II. This is where Nietzsche most directly addresses the problem of truth. 5

In Book II, in the section "On Self Overcoming," Nietzsche expresses a thought similar to that found in "On Truth and Lies in a Nonmoral Sense." In the context of the "will to truth" he states:

Evil I call it, and misanthropic-all this teaching of the One and the Plenum and the Unmoved and the Sated and the Permanent. All the permanent-that is only a parable. And the poets lie too much.

It is of time and becoming that the best parables should speak: let them be a praise and a justification of all impermanence (84-85).

He continues further on:

But this is what the will to truth should mean to you: that everything be changed into what is thinkable for man, visible for man, feelable by man (86).

Nietzsche's Zarathustra announces a philosophy of creativity, one in which the new "creators" overcome the mundaneity and the false imagery of the all too human. Truth here, as the desire for permanent truth and knowledge, is a mere "will to truth," a striving for the permanent in the face of the impermanent. It is to be superseded by the new creators" celebration of the flux. This is the "will to power" in which newness, overcoming, a fullness of life is sought over and above a drive toward collecting "facts." The permanent is a parable, and a lying one at that.

In Book I of Zarathustra, "Zarathustra's Prologue," Nietzsche contrasts this man of knowledge, the "last man" with the one who overcomes him, the Ubermensch. This Ubermensch is an artist, one who

5 Since Nietzsche so closely connects truth with interpretation, it would violate the spirit of his work to say that there is only one correct reading of Nietzsche on truth and that this paper performs that reading correctly or not. 
boldly realizes the error of the last man. The Übermensch is open and aware of the discord and upheaval that is more truly real. Nietzsche declares:

"I say unto you: one must still have chaos in oneself to be able to give birth to a dancing star" (17).

This chaos is the other side of the will to order of the will to truth. Out of this chaos, and in spite of the last men, the dancing star will be born. The role of this chaos cannot be underestimated in the problematic of Nietzsche and truth. Chaos is the denial of the orderly and the immutable. To recognize this chaos requires courage, the fear of it establishes the noble lie of permanence. In Zarathustra Nietzsche makes an artistic reappropriation of the effects of truth. The artist, as creator, does not set upon the path toward permanence, but change, not stasis, but kinesis. The effect of truth as a will toward truth, a drive to the solid and foundational is to be overcome by laughing, dancing creators who realize the impossibility of this. Nietzsche's recognition of this ontological chaos or flux is the essential element of his theory of truth.

Beyond Good and Eoil expands on Nietzsche's questioning of the "will to truth." "What in us really wants truth?" "Why not rather untruth? and uncesiainty? even ignorance?." So Nietzsche ponders. The belief in absolute truth is found to be one more construct of dogmatic metaphysicians, as part of their "religion," their "faith," "in opposite values." By this faith, what is true is taken to be the opposite of what is apparent, the apparent world is a world of falseness while the true world lies behind it. Nietzsche replies to this:

Behind all logic and its seeming sovereignty of movement, too, there stand valuations or, more clearly, physiological demands for the preservation of a certain type of life. For example, that the definite should be worth more than the indefinite, and mere appearance worth less than "truth" - such estimates might be, in spite of their regulative importance for us, nevertheless mere foreground estimates, a certain kind of niaserie which may be necessary for the preservation of just such beings as we are. Supposing, that is, that not just man is the "measure of things" (201).

Nietzsche's theory of truth has developed to an understanding of truth as a "useful error" (Will to Power). These foolish "foreground estimates" only pose a hope that beyond the perspectival variegation of the apparent lies the true, the stable and the really real. By the "faith in opposite 
values" one believes that what is really real is not the apparent but something else.

Nietzsche's "perspectivism" is expressed rather obliquely. He uses this word only about three times in Beyond Good and Evil, and even then in somewhat different contexts. To call Nietzsche's theory "perspectivism" is in some sense to impose an interpretation on Nietzsche's text; to render a stability from his fluxive, multifaceted text. One of the drawbacks of this project of interpreting Nietzsche is that it must impose some point of analysis in order to "solidify" the reading that takes place here. Thus, the decision is made to regard perspectivism as fundamental to Nietzsche's theory of truth (a theory that is itself a product of an interpretation). 6 Perspectivism states that what is true is a product of how one sees things and that how one sees things is different depending on who, what and where one is. A frog has a strikingly different perspective from a metaphysician, and correspondingly, a strikingly different conception of what is real and true. Though the point is possibly a phenomenological one, Nietzsche is not, first and foremost a phenomenologist. More prominently he is a critic of ethics and metaphysics and a philosopher of creativity over and above existing social and scientific standards. In Beyond Good and Evil, Nietzsche poses a new kind of thinker, a "philosopher of the dangerous maybe," one who recognizes the possibility that perhaps all is uncertain. This thinker takes untruth as a condition of life and goes beyond good and evil. These philosophers recognize the importance of living without certainty. Nietzsche's perspectivism stands mainly as a position of skepticism toward dogmatic understandings of what is the true.

In "How the 'Real [true] World' at Last Became a Myth: History of an Error," in Twilight of the Idols Nietzsche poses his theory of truth within a critical discussion of the history of the metaphysics of truth. In this "history of an error," Nietzsche gives six stages of the way metaphysicians have understood the world. Of primary interest here are stages five and six.

These last two stages are, arguably, two stages of Nietzsche's own development. In the fifth stage, the idea of the real, true world above and beyond the sensible, apparent world is recognized as useless, superfluous, it is to be abolished. This stage goes beyond stage four's positivistic bracketing off of a true but unattainable world to the deniability of the sensibleness of this concept. Now is "the return of cheerfulness and good sense," a time when all free spirits run riot. This proclaims the final stage, that of the Übermensch, "incipit Zarathustra." Nietzsche writes:

6 Though more support is given for this in The Will to Power, even there, the theory of truth as "Perspectivism" is established in a fragmentary way. Tying it together is a matter of interpretation. 
We have abolished the real world: what world is left? The apparent world perhaps? But no! with the real world we have also abolished the apparent world! (41).

Nietzsche calls this "the mid-day, the end of the longest error and the zenith of mankind" (41).

There is a development evidenced here in the implicit theory of truth contained in these passages. Twilight of the Idols is one of the last of Nietzsche's writings. There is a recognition that the dualism of the real and apparent worlds is not only refuted and forgotten, but also that, as the real world is abolished so is the apparent world. Seemingly, up until this point (1888), it has been a central tenet of Nietzsche's understanding of truth that there is a separation between what is regarded as true, perspectivally, with each language, group, culture, and point of view, et cetera, each making a determination of what is the true, and what is outside of all this-an ultimate reality, existing, if only, as a chaotic flux. One might ask whether "How the 'Real World' at Last Became a Myth," in fact, constitutes a denial of perspectivism? Before turning to this issue, one more text ought to be considered.

An examination of The Will to Power, can serve as an important afternote to this generally chronological account of Nietzsche on truth. In this posthumous collocation is Nietzsche's strongest affirmation of a perspectival theory of truth. In The Will to Power Nietzsche regards truth as a kind of error useful to life (section 493, from 1885). A priori truths are considered to be merely provisional assumptions. Nietzsche writes in section 552:

"Truth" is therefore not something there, that might be found or discovered-but something that must be created and that gives a name to a process, or rather to a will to overcome that has in itself no end-introducing truth, as a processus in infinitum, an active determining-not a becoming-conscious of something that is in itself firm and determined (298).

Ultimately what matters is interpretation. Nietzsche remarks:

In so far as the word "knowledge" has any meaning, the world is knowable; but it is interpretable otherwise, it has no meaning behind it, but countless meanings.Perspectivism."

It is our needs that interpret the world; our drives and their For and Against. Every drive is a kind of lust to rule; each one has its perspective that it would like to 
compel all the other drives to accept as a norm. (Section 481, pg. 267).

Section 604 claims:

"Interpretation," the introduction of meaning--not "explanation" (in most cases a new interpretation over an old interpretation that has become incomprehensible, that is now itself only a sign). There are no facts, everything is in flux, incomprehensible, elusive, what is relatively most enduring is-our opinions (327).

Absolute, stable truth is denied. There are no "facts." Interpretation in the interest of preserving life is, in the final analysis, all that remains of the once exalted concept of truth. The question of whether these passages from The Will to Power "square" with what Nietzsche writes in "The History of an Error" is in some sense put in abeyance. What Nietzsche says here mitigates against the apparent monism of "stage six." Here Nietzsche is as critical of monism (what is suggested by "stage six") as he is of dualism. Still, the question of whether the abolishment of the apparent with the real world mitigates against a dichotomy of perspective and flux is a challenging one. Clearly "stage six" and the "Perspective-flux" dichotomy are both set in opposition to any metaphysical realism (see the earlier reference to Hilary Putnam). Perhaps it is helpful to question what the "perspective-flux" dichotomy entails.

The initial question of this paper asked of Nietzsche's theory of truth was whether its perspectivism committed an undermining fallacy of relativism, such that it posited one ultimately true absolute fact, namely that all truths are perspectival. It bears asking whether Nietzsche's theory of truth can evade some logical problems posed to it. First, if the theory is perspectival, then what is each perspective a perspective of? When one compares an object viewed from the perspective of a frog with that of a giant, their perspectives are different but, by the logic of the notion of perspective, there must be some objective thing of which both perspectives are perspectives. Nietzsche denies that there is an outside world that is to be contrasted with an inside one. Is Nietzsche a phenomenalist? Does he believe only in phenomena? In fact Nietzsche is critical of the phenomenalist point of view. The dichotomy of perspective and flux presupposes that one determines what truth is from a perspective, that which is useful to that form of life. "Perspectivism" is, perhaps, an incomplete metaphor in that it must not be taken to imply that there is a perspective of something. Unlike the painter who paints an object from one perspective or another, here there is no external object. Really, there is no one "objective" point of view. Outside of the perspective are not any really real things in themselves but only an undetermined flux. If Nietzsche does 
posit a world outside of our perceptions, it is a world of indeterminacy, chaos, a world gathered together into objects by those creators who recognize this.

Perhaps this is where the "Stage Six" monism and Nietzsche's perspectivism come together. Nietzsche avoids the dualism of a perceptual inner and perceived outer world. With the real world, the apparent world also vanishes. The apparent world is a product of the belief in the real world. This leads, perhaps, to a solution to the "paradox" of relativism discussed earlier. For Nietzsche, the world is a product of perspectival interpretations, not perspectives of some true world. The perspectives decide on how the world is, according to what preserves life. Nietzsche can be interpreted not as denying that there is an absolute perspective, or "true reality," but rather, if such a "perspective" does exist, it is only one of flux, the laws, objects, realities of any individual perspective not having been yet discovered or yet "decided" upon.

It denies the force of Nietzsche's arguments to say that there is only one interpretation of Nietzsche on truth. Nietzsche's texts can be read in many ways. What is provided here is only one way, but one supported by textual analysis. Whether it is even worthwhile, for example, to speak of a "perspective-flux dichotomy" may be the point of the "History of an Error" stage six. Taken as a whole, Nietzsche's text exhibits both developments and ambiguities. To say that Nietzsche has a unitary theory of truth is, to a certain extent, to be anti-Nietzschean. Nietzsche is the philosopher of the dangerous maybe. Like Emerson, he does not recognize consistency as the highest ideal. In breaking with the notion of truth as certainty he must allow for uncertainty, even in the understanding of his own writings. In Ecce Homo he writes:

Is Hamlet understood? Not, doubt, certainty is what drives one insane.- But one must be profound, an abyss, a philosopher to feel that way.-We are all afraid of truth (246).

In The Will to Power Nietzsche recommends:

An anti-metaphysical view of the world--yes but an artistic one (The Will to Power, Section 1048. pg. 539).

Bibliography

Allison, David B (ed.). The New Nietzsche. Cambridge: MIT Press, 1985. 
Babich, Babette. "Nietzsche and the Philosophy of Scientific Power: Will to Power as Constructive Interpretation." International Studies in Philosophy. V. XXII/2 1990. Pp. 79-92.

Clark, Maudemarie. Nietzsche on Truth and Philosophy. CAmbridge: Cambridge University Press, 1990.

Conway, Daniel. "Beyond Realism: Nietzsche's New Infinite." International Studies in Philosophy. V. XXII/2 1990. Pp. 93-110.

Danto, Arthur. "Nietzsche's Perspectivism." In Solomon, Robert (ed.). Nietzsche, a Collection of Essays. Notre Dame: University of Notre Dame Press, 1973. Pp. 29-57.

Emerson, Ralph Waldo. Selected Essays. Ed. by Larzer Ziff. New York: Penguin, 1985.

Foucault, Michel. The Order of Things. New York: Vintage Books, 1973.

Heidegger, Martin. "The Essence of Truth." From D. Krell, ed. Martin Heidegger: Basic Writings.

Heidegger, Martin. Nietzsche: Volume III: The Will to Power as Knowledge and as Metaphysics. Trans. by J. Stambaugh, D. Krell, F. Capuzzi. San Francisco: Harper and Row, 1987.

Kant, Immanuel. Critique of Practical Reason. Trans. by Lewis White Beck. Indianapolis: Bobbs-Merrill, 1956.

Krell, David Farrell. Nietzsche and the Task of Thinking: Martin Heidegger's Reading of Nietzsche. Dissertation: Duquesne University, 1971.

Nietzsche, Friedrich. Beyond Good and Evil. In Basic Writings of Nietzsche. Trans. and ed. by Walter Kaufmann. New York: The Modern Library, 1968.

Nietzsche, Friedrich. Ecce Homo. Trans. by Walter Kaufmann. New York: Vintage Books, 1969.

Nietzsche, Friedrich. Philosophy and Truth: Selections from Nietzsche's Notebooks of the Early 1870's. Ed. and trans. by Danicl Breazealc. New Jersey: Humanities Press International, 1979. 
Nietzsche, Friedrich. Thus Spoke Zarathustra. Trans. by Walter Kaufmann. New York: Penguin Books, 1966.

Nietzsche, Friedrich. Twilight of the Idols. Trans. by R.J. Hollingdale. New York: Penguin Books, 1968.

Nietzsche, Friedrich. The Will to Power. Trans. and ed. by Walter Kaufmann and R.J. Hollingdale. New York: Vintage, 1968.

Ormiston, Gayle and Schrift, Alan. Transforming the Hermeneutic Context: From Nietzsche to Nancy. Albany: SUNY Press, 1990.

Plato. Theatetus. Trans. by Francis Cornford. Indianapolis: Library of Liberal Arts, 1957.

Pöggeler, Otto. Martin Heidegger's Path of Thinking. Trans. by Daniel Magurshak and Sigmund Barber. New Jersey: Humanities Press, 1987.

Putnam, Hilary. Reason, Truth and History. New York: Cambridge University Press, 1981.

Shapiro, Gary. Nietzschean Narratives. Bloomington: Indiana University Press, 1989.

Wilcox, John. Truth and Value in Nietzsche. Ann Arbor: University of Michigan Press, 1974. 